\title{
RUMOR, HUMOR, AND OTHER FORMS OF ELECTION FOLKLORE IN NON-DEMOCRATIC SOCIETIES: THE CASE OF BELARUS
}

\author{
Anastasiya Astapova \\ Department of Estonian and Comparative Folklore \\ University of Tartu, Estonia \\ e-mail: anastasiya.ast@gmail.com
}

\begin{abstract}
This article focuses on folk expressions on "the election without choice", as the state elections in authoritarian societies are often labeled. The research is based on the case of Belarus, where the electoral fraud has become a matter of common knowledge both for the Belarusians themselves and outside observers. Yet, even though the independent opinion polls are not exactly as positive for the Belarusian president as the official results of the election, they show that Alexander Lukashenko wins within the self-sufficient system he has created. This hegemony is nurtured, for instance, by various manifestations of the election sham reproduced by Belarusians. At the same time, the election rumors and jokes circulating in the oral communication and on the Internet question the existing hegemony. By means of fieldwork examples I show in this article how the genres of rumors and jokes are interconnected, sometimes to the point of being indiscernible. Rather than looking at the borders of the two genres, I will concentrate on their interplay, intertextual bridges between them, the ideologies they share, and new directions for understanding the non-verifiable folklore they provide.
\end{abstract}

Keywords: Belarus, election folklore, election fraud, genres, humor, intertextuality, jokes, rumors

On Sunday, October 11, 2015, I decided to discharge my civic duty of a Belarusian citizen by voting in the presidential election. As I live outside of Belarus with an Estonian residence permit, I went to the Belarusian embassy in Tallinn to vote. The personnel were very welcoming, and the procedure did not take long. The employees of the embassy asked me for a passport, filled out my data in their papers, and issued a ballot to me. I made my choice in the voting booth, put the ballot into the ballot box, thanked the personnel, and left - following the election procedure typical all over the world.

Once I had left the embassy, however, questions about how typical the procedure was started to rise in my head. The personnel of the embassy did not 
ask for my Estonian residence permit - how could they be sure that I lived in Estonia? They did not check it in any lists or databases; they only had tables on paper where they recorded my name. How did they know that I did not vote in the same way in the Belarusian Embassy in Latvia, Lithuania, Russia, and even in Belarus itself - taking into account the fact that the preliminary voting for those who cannot vote on the Election Day began five days before, on October 6? Had they later discovered my multiple votes by comparing their lists with other embassies, how would they have found which ballots were mine to make sure that their multiplicity would not have influenced the election results? Can the voters just purposefully "haul" from one poll to the next? These multiple questions were followed by the feeling of disappointment over how useless my voting might have been.

Posing these questions already required vernacular terminology to refer to potential fraud in such a situation. Multiple votes at several polling stations, until recently possible in the United States, were called "floating" or "boodle" (Sarvis 1998: 52). In Belarus, the practice of voting multiple times acquired the name of "merry-go-round" (karusel'), with people paid to take part in it called "merry-go-rounders" (karusel'chiki) (United Civil Party 2015). As I will show further, there is a broad vocabulary for the description of potentially fraudulent elections in its different aspects.

In addition to this vernacular terminology, I started to think about multiple rumors I had heard before the Belarusian presidential election, all accusing it of fraud. Since its 1994 declaration of independence from the Soviet Union, Belarus has had five elections, and at least the three of them that I remember were accompanied by rumors, bitter jokes about the situation, and many other forms and genres of folklore. For instance, at the 2015 elections, the opposition claimed that all the voices would be faked, and called for the boycott of the elections. Undoubtedly, this specific vernacular reaction appears due to the fact that at each and every election one and the same person - Alexander Lukashenko - has won, allowing many to consider Belarus an authoritarian society. Rich folklore, however, accompanies all elections, not only those conducted in dictatorships.

\section{ELECTION FOLKLORE}

Elections have been studied extensively in political science, both synchronically and diachronically. Folklorists, however, have not paid much attention to elections, apart from the random recognition of expressive culture associated with Election Days (Sarvis 1998: 42). The majority of existing works on elections 
are based on US materials. One may suppose that rich Election Day traditions emerged due to the strong narrative of American democracy. Indeed, works on American nationalism show how special the character of political engagement is in American elections (Dinkin 2002; Gamber \& Grossberg \& Hartog 2003; Patterson 2003; Schudson 1998). Due to this, American folklorists often analyze Election Day celebrations per se (Fabre 1993; Santino 1994; White 1993) or separate issues which become particularly important at certain elections (Granberg \& Burlison 1983). Meanwhile, as far as I know, only one piece of research concentrates on the rumors of election fraud (Sarvis 1998). Its author, writing about such rumors in postwar rural Missouri, claims that "election fraud is an appropriate subject for oral history and folklore in common with many other topics that involve truth, even though they will not pass the rigors of logics and 'proof' required in courts of law or in history articles" (Sarvis 1998: 69). In the United States, he argues, the great deal of reasonable doubt, the time factor, and the potential expenses keep election fraud testimonies outside of the judicial system, and thus beyond rigorous examination for truth, belief, and invention. "But truth, belief, and invention exist in the oral tradition, and the folklore legacy of election fraud in itself contributes profoundly to suspicion and distrust, even paranoia, around election time in certain locales" (Sarvis 1998: 69). Of course, the situation in Belarus is very different both from postwar Missouri and today's American elections. For instance, different reasons, such as fear and Soviet election tradition, keep Belarusians from examining election fraud rumors in court. Nevertheless, I will draw on the material provided by American researchers, who were among the first to recognize the potential of election folklore analysis.

There are some studies on elections that also go beyond the American focus. For instance, there is a 1994 collection of urban legends related to South-African elections. One of the most prominent stories in it is "Ink in the porridge". According to it, one of the opposition leaders claimed that the National Party offered porridge laced with ink to black voters. The intent was that the ink would show up under the ultraviolet lamps on the Election Day, and the black voters who consumed it would be disqualified from voting for the African National Congress - the main opposition to the National Party (Goldstuck 1994; Kaschula 2004: 867). Such conspiracy theories often become relevant at the elections. One of the most well-known examples is that following the election of the first US African-American president, a wave of conspiracy theorists rose to prominence through claims that Barack Obama was not a natural-born citizen (Gencarella 2010: 260). They argued that he had not been born in Hawaii, but rather in Kenya (there are other versions as well); thus, he is not a natural-born citizen of the United States and is ineligible to be a president of the country. These 
rumors became a tool for othering Obama and expressing discontent with him through the assumption of his illegitimacy as a president. Both African and American examples concern race, although this is not always the case in the election folklore in other societies.

Quite a bit has been written on the Iranian elections: folk expressions, postelection protests, and the Internet, among other driving forces (Honari 2014; Kamalipour 2010; Rahimi 2013, etc.). Several scholars concentrate on the voting cultures emerging after the Arab Spring (Davis 2013; Muravchik 2013; Weddady \& Ahmari 2012, etc.). Isolated studies exist on election humor and protest in post-Soviet bloc countries like Russia (Alekseevsky 2010; Arkhipova 2012; Arkhipova \& Alekseevsky 2014; Erpyleva \& Magun 2014) and Hungary (Varga 2015). The Soviet elections have become a matter of thorough analysis by many scholars, almost none of them folklorists. Among unconventional objects for analysis, archival research also allows for access to messages that non-conforming voters put in the ballot boxes or wrote on the ballots during Soviet elections (Kozlov \& Mironenko 2005; Merl 2011). These messages often openly address and criticize political leaders or carry complaints about how poor the citizens' lives are.

The list above is not, of course, exhaustive, but is meant to highlight the main research directions in the rather undeveloped field of election folklore analysis. Many other phenomena of electoral creativity in Western democracies remain unaddressed in the research: for example, non-human electoral candidates, practical jokes during elections (when the voters are informed that the election has been cancelled (Watts 2006: 125)), political parties and candidates created exclusively for frivolous purposes (parody, joke, hoax, etc., often successfully elected), various post-election protest tactics, the candidates' amulets and lucky omens, customs accompanying the closure of the polls, etc. (Pound 1959: 189).

One of the common questions asked by election research is how the voting behavior and narratives about elections reflect the voters' civil values. As Molly Anders notes, political narratives are not necessarily overtly about politics, but "these stories often reveal how individuals position themselves within the communities that they live" (Andrews 2012). Folklorist Paulina Latvala adds that narratives consist of emotions about everyday political atmosphere and many genres of political folklore represent the conflicting values - past and present - in the community (Latvala 2014: 121). It is undoubtedly within the domain of folklore studies to follow, ask about, and analyze individual positions and values of voters, expressed through different genres in various contexts. The context of the Belarusian elections may present particular interest for the folklorists, and below I am going to specify what is so distinct about it. 


\section{THE BELARUSIAN CASE}

The Belarusian case reminds us of the aforementioned idea of William Sarvis, who argued that folklore legacy of the election fraud in itself contributes profoundly to suspicion and distrust (Sarvis 1998: 69). Belarus became independent from the Soviet Union in 1991, and it is needless to say that its 70-year history within the Soviet Empire did not create a sense of honest elections (Jessen $\&$ Richter 2011). It should be mentioned from the beginning that Belarus has been undoubtedly the most Russified country within the Soviet Union, due to the similarity of the Belarusian language to Russian and the previous history of Russification within the Russian Empire. This Russification also resulted in a dedicated following of the direction sent from the Moscow center and a shock after the Soviet Union's collapse. In March 1991, 83\% of the Belarusian voters were in favor of retaining the integrity of the USSR - a higher percentage than in any other Soviet republic outside Central Asia (Blacker \& Rice 2001: 226; Rudling 2015: 2).

Still, after the Soviet Union's collapse, nationalist discourse emerged in Belarus, as it did in all the post-Soviet republics. It did not only promote the nationalist version of history, claiming that the Soviet Union had aimed to destroy the Belarusian consciousness and people, but also stimulated the replacement of the Russian language with Belarusian. The latter did not go so well, as in the post-Soviet 1990s most Belarusians could not speak their own language, and the language itself was not ready to be fully implemented: for instance, it lacked scientific and political terminology (Rudling 2015: 211). In addition, the new national symbols proposed were associated with World War II collaborationists who were condemned throughout the Soviet period. All these nationalist changes were imposed too hastily by the Belarusian Popular Front Party and its leader, Zianon Pazniak. Belarusians did not identify with the newly offered consciousness, and the surgical operation of the immediate separation of the Belarusian and Soviet ideology could not be successful (Bekus 2010: 80).

Small wonder that when Alexander Lukashenko, opposing radical nationalism and promising to preserve many Soviet Empire values in his "retro-project" (Bugrova 1998: 32), showed up on the political arena, he immediately won the hearts and votes of the Belarusians. He became a certain relief for the majority of Belarusians, doubting the hastily implemented and strange nationalist discourse. Challenging the nationalist inclination of the new Belarus, proposed by Zianon Pazniak, Lukashenko promised familiar stability. This was a much more important matter for the people who had experienced the uncertainty and economic difficulties of transitional post-Soviet years than the imagined return 
to Europe. Lukashenko beat Zianon Pazniak at the first, 1994 presidential election, gaining $44.82 \%$ of votes in the first round and $80.1 \%$ in the second one.

After this victory, Lukashenko gained more and more popularity by preserving what he had promised; this allowed him to hold a referendum in 1996 to change the constitution and to start his 5-year term count anew. The referendum was unacknowledged by Europe and the United States (BBC news 2006) and considered fraudulent by the opponents of Lukashenko. In 1999, opposition members declared Lukashenko's presidential term over, protested openly, and tried to hold an alternative election. Their major candidate was soon imprisoned and the protests were violently suppressed.

The 2001 election, at which Lukashenko won again, was characterized by the Organization for Security and Co-operation in Europe (OSCE) as undemocratic and unfair (BBC news 2001). Yet, according to the constitution, it seemed that this was Lukashenko's last term. To secure his place, however, he held a new referendum in 2004, offering the following question:

Do you permit the first President of the Republic of Belarus, Lukashenko A.G., to participate as a candidate for Presidency of the Republic of Belarus during the presidential elections, and do you accept Part I of Article 81 of the Constitution of the Republic of Belarus in the following wording:

"President is elected for the term of 5 years directly by the people of the Republic of Belarus by means of the universal, free, equal, and direct suffrage by voting by secret ballot"? (The Central Commission 2004)

According to the results of the 2004 referendum, the majority of voters allowed Lukashenko to change the constitution and to participate in an unlimited number of new elections. Despite multiple objections of the opposition, he used this possibility in 2006, winning his third election. The third election in 2006 and the fourth one in 2010 were accompanied by plenty of protests, which were violently suppressed by the government. The latest, fifth election (2015) included four candidates, a female candidate from the opposition among them. According to the official statement, the results were as follows: Alexander Lukashenko 83.47\%, Tatiana Karatkevich 4.44\%, Sergei Gaidukevich 3.30\%, Nikolai Ulakhovich $1.67 \%$, against all $-6.32 \%$ (Naviny.by 2015a). This election gathered only a few protesters in the streets of the capital.

Every election since at least 2001, including the last one, has been accompanied with accusations of fraud by the opposition and the disapproval of the international observers. It is hard to say whether fraud - the main topic of the Belarusian election folklore - has taken place, and if it has, then to what extent. Still, there is no doubt that there are many fundamental flaws in the electoral process, of which many are specific to the political situation in Bela- 
rus and recognized by the political science researchers. Undoubtedly, the current Belarusian state is not accustomed to opposition and does everything in its power to block it. The campaign environment seriously disadvantages the opposition candidates; oppositional activists are intimidated. State-controlled media is highly biased in favor of Lukashenko and the independent print media is censored. Extensive power of executive structures allows for the electoral environment to be arbitrarily changed; weak legislative framework fails to ensure independent legislative bodies and imposes excessive restrictions on campaigning and observers (Korosteleva \& Lawson \& Marsh 2003: 193-194). To conclude, the elections in Belarus are held "freely, but under unfair circumstances" (ibid.: 194). The authoritarian leadership wins at what is represented as democratic elections. Even if the opinion polls are not exactly as positive as the results of the election, one has to recognize that Lukashenko wins within the system he himself has created.

To imagine the situation better, one must keep in mind that Lukashenko gained power over a country which was still very Soviet, promised to preserve many Soviet values, and has been quite successful in it. Modern Belarus is often compared to the Brezhnev Era of Stagnation (Savchenko 2009: 188), the state of being stagnant, or not moving, not as horrifying as the Stalinist time, but still far from being a democracy. Further on I will show how the Belarusian voters reproduce the system, making it more and more self-sufficient. At the same time there is no contradiction between reproducing and defying the system, both of which coexist in Belarus.

As James Scott claims, subordinates react to what is imposed on them by power holders in different folk expressive ways, including rumor, gossip, jokes, and rituals, among others (Scott 1990: 19). What is more, if the domination is particularly severe, it is likely to produce folk expression of corresponding richness (ibid.: 27). Indeed, Belarusian election folklore has become so widespread and creative that its genres intermingle to the extent that it is impossible to tell one from another; they move from one election to the next whether through oral communication, news, or the Internet.

\section{METHODOLOGY OF FIELDWORK AND ANALYSIS}

The material collected for this article was drawn from two sources. First, in 2011-2015, I carried out over fifty informal, open-ended interviews about the issues of political and ethnic identity with Belarusians living in Belarus and those who had emigrated from the country. Most of the interviews were held in Vitebsk and Minsk; some were held among the Belarusian diaspora in foreign 
countries - Russia, the United Kingdom, the United States, Poland, Estonia, Lithuania, and China. I mostly interviewed those who volunteered for it. For instance, Belarusian friends posted information on social networking sites, announcing that there would be a native scholar coming to Belarus, researching political and ethnic identity. Correspondingly, those people who were interested in voicing their opinion on these issues contacted me. Also, whenever I went to a foreign country, I looked for Belarusians there through acquaintances in Belarus (and Belarusian diasporas) or through simply searching for Belarusians on the Internet in the countries I was visiting (these were mainly very active people I could find through googling, for instance, 'Belarusians in China'). Through these methods, I found and interviewed most of the respondents; these were mainly men aged between twenty-five to forty-five years, who volunteered to be interviewed on the subject of politics. It seems to me that they were representative of the politically aware and interested part of the Belarusian society and diasporas. Compared to many others, who were reluctant to speak about politics, they form a rather distinctive sample characterized by sensitivity towards, concern about, and awareness of political issues, as well as by openness to discuss them. At the same time, the interviewees were of different political mindsets, not necessarily oppositional to the current government. I have mentioned that the majority of the informants were males, and the position of many women regarding politics in Belarus, meanwhile, is well-characterized by the following excerpt from an interview:

- Do you think that the elections may have been falsified?

- Yes, there were many proofs, I think. Formerly I was younger and more passionate, but my parents laughed at me, understanding that we cannot change anything. Formerly I could not understand them; I asked, "Mom, why don't you go to protest?", but now I also think like they do, and I understand that many positive things are done in our country too. Culture is being developed now, journalists write about culture, handmade art develops. I am a girl and I do not interfere in politics.

(Recorded from a 21-year-old female in Minsk, 2012 (emphasis mine))

This interview is representative of a widespread position of women regarding the Belarusian political situation. They often claim that people themselves cannot change anything in the country, are satisfied with positive developments, and self-identify as women who are not supposed to deal with politics or even have a strong opinion on it. Undoubtedly, I cannot judge for the whole Belarusian female population, as I have not done any statistical research, but several interviews (as quoted above) and the general reluctance of Belarusian women to participate in the research on politics were quite demonstrative. At 
the same time, I had at least three interviews with females expressing their political position with confidence.

Due to anonymity promised to the participants, the interviews have only very basic references: I mention where and when the interview was recorded as well as the age and gender of the interviewees. Before the interviews, I prepared a basic plan of the main topics and questions to ask, including the general election and the possibility of frauds in its results. I did not always follow the interview plan, but let the interviewee speak more on the issues he or she was interested in. This means that some interviews contain large pieces on the election, while others carry almost no opinion on it at all. Many interviews also contain election jokes, which are among the most popular political jokes in Belarus, told not only around the time of the election.

Having conducted all these interviews, unfortunately, I did not have a chance to be in the country during the latest, 2015 election. That is why I decided to complement the interview data with distance fieldwork on the Internet. In addition to real-life fieldwork, this is the second source of my research. Firstly, the article is largely based on the election folklore my Belarusian friends shared via social networks. This is the approximate collection of rumors, jokes, and other genres accessible to the average Belarusian Internet-user, who can be both an active promoter and a passive receiver. They mainly appear in the internet statuses and reposts of certain groups from Facebook and its Russian-language analogue Vkontakte (www.vk.com). To guarantee anonymity to the informants who did not even know that they were my informants, I have omitted all their data; hopefully, by translating the material from Russian or Belarusian into English, I have made its search on the Internet more difficult. Secondly, I browsed the news and comments upon the 2015 election results on the main Belarusian online mass media. Thirdly, I went through the hashtags on Facebook and Twitter, all related to the Belarusian 2015 election: \#vybar_by ('election_by', the most widespread one),\#выборы_без_выбора ('election_without_choice'), \#выборытут ('election here'), \#БеларусьВыбирает ('Belarus elects'), \#Выборы2015 ('Elections 2015'), \#naziranne ('observation' in Belarusian), \#BSDP (the abbreviation for the oppositional Belarusian Social Democratic Party Hramada). Finally, I examined a comparatively new group that emerged in the Russian-language social network website Vkontakte. The group Grustnyi Kolen'ka ('Sad Kolen'ka') appeared before the 2015 presidential election (Vk.com 2015); it posts as if on behalf of the youngest son of Lukashenko, Kolya (born in 2004). The name of Kolya's mother is still unknown, but Kolya is obviously the apple of his father's eye, being brought to all sorts of official events and places, from churches to military parades. In addition to popular indignation over this, the figure of little Kolya is surrounded with rumors - not only who his mother really is and 
how terribly capricious, if not psychologically unstable, he himself is. According to recurrent half-joking folk statements, Lukashenko prepares Kolya for the presidency. Due to the fact that in an authoritarian society Lukashenko is the only widely known official actor of Belarusian politics (an average Belarusian will hardly even remember the name of the prime minister), another known figure, Kolya, also becomes a protagonist both of rumors and jokes.

The posts in one Vkontakte group (with more than 2300 members at the time of writing this article), jokingly attributed to Kolya, comment on Belarusian current events and his life with his father. It opened a few months before the 2015 election.

Just imagine, daddy snores the hymn of Belarus. (November 3)

Daddy is lucky. I always have to learn different poems at school, while he learns the same inauguration text every time. (November 1)

Today BATE [the Belarusian football club] plays with Barcelona. The intrigue is comparable to that at the Belarusian election. (October 20)

Many of Kolen'ka's posts are also about the elections, and I will further use them in the article. The Internet in general becomes a significant scene and a meeting ground for questioning the existing system - as the real protests are suppressed and the access to offline public space is limited and regulated.

Undoubtedly, a major source of the election folklore is the accounts people give on how they voted, although the Internet is now becoming an important environment giving way to new forms of communication. Among the most unusual and rare forms on the Internet, I should single out the game available on Google Play, dedicated to the Belarusian elections, with the following description:

Do you know there are "president elections" in Belarus this year? Unfortunately wind of change has blown all the candidates away. And they're leaving using air balloons. But no candidates - no elections... You're playing as Master Lida - well known belarusian [sic] elections wizard. And you must stop all the candidates from leaving the elections. So take your gun and start your job:) And remember: elections results depends [sic] on you now! Only on you :) (Google play 2015)

The irony of the description is first of all in calling Lydia Ermoshina, the chairwoman of the Central Election Commission of Belarus, often accused of arranging the election fraud, an election wizard. Secondly, the final sentences of the text mock the agency of Belarusians: the election results depend on them in the computer game only. It is a common phrase in Belarus that "everything 
has been decided for us", meaning that Lukashenko will be elected anyway, no matter how one votes.

Another comparatively old genre, which has now gone viral due to the Internet, is when people request their co-citizens to participate in the election and vote for Lukashenko. As many of my interviewees reported, people working in state organizations - schools, hospitals, universities - are usually forced to make those calls on the Internet. These videos are not funded in any way; people have to make them on their own, and they are usually very unprofessional. A typical video takes place in the street where a young speaker with the Belarusian flag is supposed to utter a text similar to the following: "I am going to the election because I have an active civil position, and I will vote for a strong and independent Republic of Belarus!" (Youtube 2015). It is mainly younger people who are involved in the voting campaign, for Lukashenko in particular. Similar to the Soviet Union (Tsipursky 2011), the election becomes a venue for the expression of youth agency, allowing the government to appear as if it conveyed the desires of the next generation, also teaching them how to behave according to the political requirements of the state. Finally, low level of professionalism in making videos is perhaps supposed to be a sign of authenticity - people themselves striving to agitate for Lukashenko with the sources at hand.

In response, however, the opponents of Lukashenko, also quite young, make videos calling for a different action. In a short film made by a Belarusian student, a young man comes to visit his grandmother, when two activists ring her doorbell to collect signatures for Lukashenko. After they have made the grandmother believe how good Lukashenko is, they ask her to bring her passport to sign for his candidacy. Her grandson immediately rushes to her bedroom and hides the passport. The video ends with the text: "19 December [the day of the Belarusian election 2010]. Hide grandmother's passport” (Ru.tsn.ua 2010). Elderly females are Lukashenko's main supporters, and the video suggests eliminating their votes. The video was created to go viral, attract Internet users, and make them further disseminate the link through reposting and sending it to friends. It has been reported, however, that the student who had made this video was fired from his state job (ibid.).

In addition to these rather random examples, the major part of the article below will be dedicated to the most recurrent themes and genres of the Belarusian election folklore. I have divided the article into several subchapters for the sake of structure, but, as the reader will see further, the borders between motives, genres, and issues are fuzzy as there are no clear-cut categories in the material. Constant tension between Lukashenko's followers and their opponents undoubtedly increases during the election, reinforcing a variety of existing intermingling political folklore motives. 


\section{FOODWAYS AND OTHER EXPRESSIONS OF POTEMKINISM AND HEGEMONY}

One of the major images of the Belarusian presidential election in 2015 was that of the food in the polling station in which Lukashenko himself voted. Figure 1, as also many other pictures on the Internet, demonstrates the abundance of dishes available in the buffet there, also at unbelievably low prices.

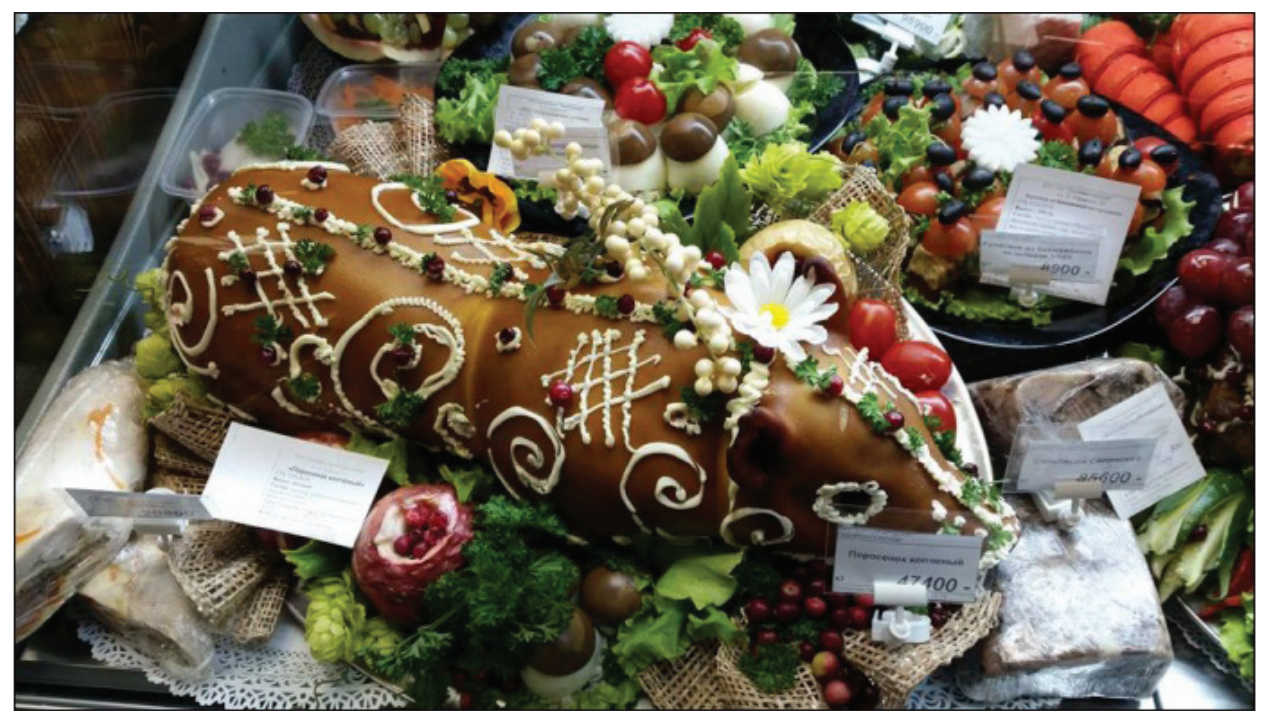

Figure 1. The buffet laid out at the polling station where Lukashenko voted (Grodno 2015). Source: http: / /grodno24.com/belarus / bufet-na-prezidentskom-uchastke-raduetizbiratelej-smeshnyimi-czenami.html.

This and other images of prosperity and plenty were paradoxically created by the citizens for the president of Belarus at the polling station where he voted. This goes in line with the general tendency of erecting false, "Potemkin" façades for the president as well as high officials in Belarus. The essence of the Belarusian Potemkinism is well conveyed by a joke in the Kolen'ka group: "Hearing the sound of daddy's helicopter, even broken combine harvesters start reaping" (Vk. com 2015). In Belarus, the common socialist phenomenon of Potemkinism was planted into the fertile ground of Soviet templates and the paternalist state with its set of reliable rules. In the Soviet period, the polling stations often provided goods otherwise not available, to attract people to participate in the elections. 
I have recorded multiple interviews about Potemkinism in Belarus, where people report about grooming special conditions when Lukashenko or other officials come to different enterprises and cities (Astapova 2015). The leader seems to provide peace, prosperity, and stability, and Belarusians, in return, play according to imposed rules. They reproduce the hegemony by participating in the offered system, which seems to be paid off by socialist guarantees and other benefits.

Many fragments of the interviews about the elections I recorded were also associated with pleasing the president: for instance, many interviewees employed by state-funded organizations reported on having had to collect signatures for Lukashenko before the election. They often had fewer signatures than expected, which was a matter of concern and caused fear of problems at work as a consequence. The modality of collecting signatures for the president is similar to making fancy foods at the polling station where Lukashenko voted, and to shooting videos agitating for the president or for the election. On the one hand, people are forced to do so by minor officials; on the other, they do not openly resist, thus supporting the existing hegemony.

Another similar act of the same modality is amateur performances organized at the polling stations to entertain the voters. In addition, farmers' markets, free souvenirs (pens, notepads, etc.), and cheap alcohol available at the polling stations (Minsknews 2015) are supposed to attract more voters to have a successful election. This has been a widespread Soviet practice too, when "thousands of shows, dance performances and concerts were put on in order to entertain the voters" (Jessen \& Richter 2011: 9), staging an "election without choice" - a common reference to the elections in the authoritarian regimes (Hermet \& Rose \& Rouquie 1978). Another common definition of the elections in non-democratic societies is "rituals of consensus" (Jessen \& Richter 2011: 14), underlining the affirmation of government legitimacy (Jessen \& Richter 2011: 20; Tsipursky 2011: 88) and mass obedience (Richter 2011: 103). The activities - from coming for a buffet to performing at the election stations - become the indicators of conformism, showing the citizens' preparedness to take part in the ritual demonstration of loyalty (Jessen \& Richter 2011: 23). Such elections buttress the regime by showing that the illegitimacies of its practices have been accepted and that no action to undermine it is forthcoming (Zaslavsky \& Brym 1978: 371). Choreographing such elections includes impression management to show that the regime is based on mass support (Patzelt 2011: 141) - in other words, erecting a democratic façade in front of the dictatorial regime.

This has been the legacy of many other post-Soviet countries, Central Asian ones among others, where elections legitimate power rather than provide an opportunity to challenge it (Ó Beacháin 2011: 209). They also perform politi- 
cal agency of the people rather than really cede it. A sham election, also called a 'rubber stamp election' or a 'show election', is held without any significant political choice. Interestingly, it does not have a stable name in Russian or Belarusian, and the terms pokazatel'nye vybory or pokazushnye vybory ('show elections'), which might suit, are rarely used. An alternative notion of vybory bez vybora ('elections without choice' - as vybor is an homonym for both choice and the elections) seems to be more widespread; it even led to the creation of a hashtag for the Belarusian election \#выборы_без_выбора. The lack of choice and the impossibility of change is one of the constant topics of discussions and conclusions about the presidential election results, also reflected in humor:

There is a high probability of a victory of a dude with a moustache. (Twitter 2015)

Kolen'ka: Daddy asked me to write 'Lukashenko' in cubes of ice. I say: "Perhaps, 'eternity'?” He: "Did I say something else?” (Vk.com 2015, August 20)

[This is a reference to Hans Christian Andersen's fairy-tale “The Snow Queen", in which the Snow Queen gives a task to the little boy she kidnapped, Kai, to form the word 'eternity' from cubes of ice.]

The election in Belarus resembles a game, in which the participants must run around a chair [musical chair game], but in Belarus somebody already sits on this chair. (Vk.com 2015, September 17)

On October 11, 2015, there is an election of my daddy. Oh, I mean, the president. Although... That is right... Of my daddy. (Vk.com 2015, July 3)

Belarus holds a referendum: "Do you want Lukashenko to become President again?" The answer choices are: "Yes, I am not against this"; "No, I am not against this”. (Recorded from a 35-year-old male in Tallinn, 2012)

The head of the Central Election Commission turns to A.G. [the abbreviation for Alexander Grigorievich - the first and patronymic names of Lukashenko]: "I have two pieces of news for you: a good one and a bad one." - "Start with the bad one." - "Nobody voted for you." - "And the good one?" - "You are the president anyway". (Recorded from a 24-year-old female in Vitebsk, 2011) 
The results of the beauty contest "Miss Belorussia 2002" amazed everyone; the jury was conferring for a long time, productively though. The winner was Lukashenko. (Recorded from a 28-year-old female in London, 2011)

The sham of the Belarusian election is even more visible in the function of the election foodways. In contrast to Belarusian food abundance described by the press, Joyce M. White describes the tradition of the Election Day Cake baked in the United States by American citizens on the Election Day. The cakes are baked at home and shared with the family and friends. According to White, baking the cake is associated with the pride of successfully completing a difficult culinary task and glory in symbolically representing American ideals of democracy and freedom (White 1993). Undoubtedly, both Belarusian and American Election Day foodways legitimize the systems in which they emerge through the citizens' involvement in them. The systems are, however, based on different values - the choice in one case and the picture of plenty in the other. However, the Belarusian sham, a part of the suppressive system, is often a voluntary act. As I will show further, people participate in the election show out of their own free will, and some even initiate their own endeavors.

Accounts of Potemkinist or sham elections - whether in individual reports on voting or in the oppositional press - often involve joking. According to the words of one Twitter user, "The question of the day is: are chips expensive in the canteen?" (Twitter 2015). The canteen is obviously at a school, where the polling stations are often housed, and, according to the joke, there is no intrigue in the elections per se: even trivial food, such as chips, is of more interest. The interest in food rather than election results is also described in the following Twitter joke:

A dialogue in a buffet:

"Why is it so cheap?"

"In honor of the elections!"

"Oh, I am going to vote for Karatkevich then [the second most popular candidate after Lukashenko]. I want a second tour and the same prices again." (Twitter 2015)

The low prices of alcohol at the election buffets became another matter of multiple Twitter jokes: "At one of the polling stations everyone who voted gets 1.5 liters of beer! And everyone who voted correctly also gets a dried fish" [typical snack to go with beer in Belarus] (Twitter 2015). Trading alcohol for votes has been a common practice in many countries (Sarvis 1998: 52; Watts 2006: 
125). The Belarusian case is certainly not a pure case of trading, but a way to attract more voters to support the legitimacy of the elections (as it was in the Soviet era). The incompatibility of two constituents - the location of polling stations in schools and alcohol - also becomes a target of humor:

One of the voters decides not to stint, buys a bottle of vodka, hides it under his jacket, and asks whether he can buy cigarettes too. "Of course not," the saleswoman answers, expressing her indignation. "We are at school after all!" (Pikabu 2015)

The incompatibility of different frames is exactly what produces humor in general. According to one of the leading theories of humor, laughter emerges at the point of bisociation - the combination of two ideas from different contexts, which did not seem compatible before (Koestler 1964). When these two contexts or scripts, which were extraneous to each other before, become associated, cognitive dissonance emerges, compensated with the reaction of laughter (Attardo \& Raskin 1991). In contrast to jokes in general, where two concrete scripts come together to produce jokes, in Belarusian jokes it is the incompatibility of window-dressing and reality that produces cognitive dissonance.

The state-orchestrated exhibitions are not openly defied by their citizens: conversely, Belarusians reproduce them by shaping their behavior around these representations. Judging from the interviews, however, such representations are realized to be false, incomparable with everyday real life, when everything is much more expensive and less fancy. The humor becomes self-mocking, as it exposes the tellers' own contradictory and self-duplicitous behavior (Oring 2004: 224). As in the Soviet period, the jokes expose "the coexistence of two incongruous spheres, official and parallel, and the subject's simultaneous participation in both" (Yurchak 1997: 180). I am reluctant to claim that these jokes are indications of either resistance or disregard of the election. Rather, they are logical responses marking the natural need to react to the overwhelming sensation of the election sham and the Belarusian political system in general, the product of reflection upon what is going on, and one's own attitudes towards these circumstances. Such jokes do not just express opinions, but crystallize them in aesthetic forms (Oring 2004: 227).

Political humor in Belarus, like in other countries, is closely interrelated with rumors. To understand all the nuances of previous jokes, one, for instance, has to know of a rumor, according to which the main aim of Lukashenko is to draw the voters to the polling stations - it is only after they have voted that the results may be falsified. Drawing people - who realize that the votes they bring will be falsified - to the polling stations with food becomes one more incongruity. Many other examples also show how interrelated jokes and rumors are with the mass media. 


\section{BELARUSIAN VALUES VS. EUROPEAN DEMANDS: LUKASHENKO UNDERSTATING THE ELECTION RESULTS}

It is not only personal accounts that transmit the oral history of the election. As early as 1994, Linda Dégh thoroughly analyzed the application of mass media to create or shape new folklore (Dégh 1994: 4). The press sometimes becomes inseparable from folklore expressions, and the news turn into a folk genre. A perfect example of this is the following declaration Alexander Lukashenko made at a press conference after the 2006 election:

Yes, we falsified the latest election - I have already said it to the Westerners. 93.5\% of people voted for President Lukashenko. It is said that this is not a European figure. We turned it into 83\%. This is the truth... This is because the Europeans told us before the election: "If you have approximate European figures in the election, we will recognize your election." We tried to make them European. But also, you see, it did not work. They promised that all will be fine if the figures are European. We made them Europeanand this is not fine. (Youtube 2006)

In this statement the president, perhaps, unintentionally (Lukashenko has been notorious for his slips of the tongue) confirmed the rumors about frauds circulating around the elections. The confession was shocking, although the manipulation of the election, according to Lukashenko, was to understate the high percentage of people who vote for him. Interestingly, this confession, reflected in the news, became associated with humor: when I asked the interviewees to tell Belarusian jokes to me, one of the informants retold Lukashenko's statement, among other classical political jokes:

I remember one more slip of the tongue. After the election, I think after the previous election... He said that he got the highest percentage, but nobody believed him. And the percentage of those who voted for Lukashenko was not to the taste of some observers, perhaps, from the European Union. Then he said: they did not like such a high percentage, and we changed it to, let's say, $75 \%$, and they are still not satisfied.

(Recorded from a 35-year-old male in Tallinn, 2012)

A piece of news supporting the rumors turned into a piece of humor. The comparison of these two texts evokes many other examples when a slip of the tongue becomes meaningful, and the border between the news, rumors, and jokes fluctuates. This is further complicated by the dubious nature of Belarusian official statements and lack of sources for reliable information. 
Whether characterized as a rumor, a piece of news, or a joke, Lukashenko's confession of election fraud evokes more conclusions of a different sort. It becomes an example of what is often ascribed to non-democratic elections: dictatorships have to work at creating a façade of democracy (Patzelt 2011: 135), similarly to other cases of Potemkinism discussed above. Here, Potemkinism takes place through Lukashenko's paradoxical understating of the number of votes he received. Small wonder that Lukashenko's statement becomes confirmed by a new wave of rumors: "You know, I heard the following fact from the election commission: they were forced to decrease the votes - to hold back, as there were too many for Lukashenko" (recorded from a 30-year-old male in Minsk, 2013).

Patzelt, quoted above, adds that "in dictatorship election results can of course be manipulated in many different ways. If manipulation becomes known or even highly visible, this leads to a loss of trust and support in the regime among the followers" (Patzelt 2011: 127). The official confirmation that the elections had been falsified, even if to understate the percentage of votes for the authorities, undoubtedly posed many more questions, leading to the understanding that fraud in the other directions is also possible, if it is so openly recognized by the leading power. This certainly leads to the appearance of many more rumors, mostly ones about the overstatement of votes for Lukashenko.

\section{PRO-LUKASHENKO ELECTORAL FRAUD}

According to the narratives I recorded, the election in Belarus was falsified in a number of ways: changing the ballots at night, faking the election protocol, throwing an extra pile of fake pro-Lukashenko ballots into the ballot box:

It is a hundred percent certain that all the elections since 1994 have been falsified to a various extent. During the latest election, a rumor dominated in the intellectual and expert circles that voters were now not even needed for falsification: while before the ballots were changed at night, at one point this became unnecessary. What they did was filling out the protocol at the polling station in pencil and, on the way to the district election commission, writing in necessary numbers with a pen. Somewhere the falsifications happened this way, somewhere - through a throw-in. There were comic cases too: the commission puts up a protocol, suddenly someone who is not even in the commission runs by, tears the protocol away, and the next day a new protocol is put up, but with completely different numbers. I am not saying that this happened everywhere, but there is a system and 
there is a task, and if you do not complete it-you are doomed. How you complete it is decided by the local governor, and there are certain useful well-developed schemes I have mentioned for that. To change the bulletins at night or to fill out the results in pencil.

(Recorded from a 27-year-old male in Minsk, 2012)

The electoral frauds described in the interview above represent cases of direct purposeful falsification. Another type of fraud described is associated with misunderstanding the system due to the lack of comprehensive explanation of how the election organization works. This is not understood as illegal fraud, but as a defect of the system, which nevertheless benefits the president:

As far as I know, if 40 people out of 100 vote "none of the above", we lose these 40 votes. As far as I know, I was told: these 40 votes are given to the one who was in power before. And we had had only one person in power before. (Recorded from an 18-year-old male in Vitebsk, 2012)

I consider that the high percentage of voters for Lukashenko was achieved by taking advantage of the villages. For instance, when there was a referendum [to allow Lukashenko to change the constitution and become a candidate for an unlimited number of terms], I do not remember how the question was formulated, but it was said that the referendum was about extending Lukashenko's presidential term. Elderly people did not understand the question. They thought that Lukashenko was being impeached or something, not that the constitution would be changed. People just did not understand the question: it was posed too slyly.

(Recorded from a 45-year-old female in Vitebsk, 2013)

Election fraud has become a topic for many jokes in general. For instance, the aforementioned social network group publishing in the name of Lukashenko's son, Kolen'ka, has many of them (see Vk.com 2015):

I was exploring daddy's table and found the results of the 2015 election. They are quite ok. I think daddy will like them. (June 26)

My hand is so tired of ticking off the ballots. (October 11)

I understood that daddy would definitely win, as he had ordered to bring 200 tubes of correction fluid to the election stations. (October 11)

Why the hell are the sacks with ballots supposed to be kept in my room? (October 11) 
Daddy asked me which number sounded more credible: $79 \%$ or $86 \%$. (October 11)

Daddy explained what the secret of his success was. It turned out that one vote for him is counted for two... million. (August 3)

Conversational jokes on this topic are also frequent in the interviews. The following piece, for instance, was labeled by the interviewee as a joke: "I have a friend, who has a friend. So his acquaintance knows someone who voted for Lukashenko" (recorded from a 32-year-old male in Minsk, 2012). The humorous genre, however, is hardly discernible from belief narratives occurring in other interviews, marking the incongruence between perceptions about the elections and the official results announced by the state. The following example, for instance, touches upon the same topic - the disbelief in the election results caused by the fact that only few acquaintances of the interviewee voted for Lukashenko:

The elections were falsified. I have not counted myself, but I consider it to be so. Out of my environment only a few mentioned that they voted for Lukashenko. That is why I consider the elections to be falsified.

(Recorded from a 20-year-old male in Vitebsk, 2012)

The counter-discourse of conspiracy and rumor was undoubtedly supported by anti-Lukashenko opposition in their press, but, as it often happens, it shaped a strong commitment to the perception that the elections were no longer a secure means of displaying public opinion (Rahimi 2013: 83). Since 2011, I have recorded more than 100 texts of Belarusian political jokes, and many of them touch upon this mistrust, even in between the elections. For instance, the fourth most popular joke in my collection is about the general election; a version of it presented below was recorded in December 2012, two years after the presidential election. The same joke is told in Russia about Putin winning the election over Sarkozi and Obama (Livejournal 2012).

Obama, Putin, and Lukashenko get on a desert island, but find a boat there. Nobody wants to row. Obama says, "Nation... The US is a great nation, I am the president of the great nation, I am not going to row." Putin says, "Mmm... Russia is a powerful country, I am the president, I am not going to row." Finally Lukashenko says, "Let's conduct elections then." And then the picture changes to what happens in two hours: Obama rows one paddle and Putin rows the other. Putin says to Obama, "Listen, we are three, how did it happen that two voted for you to row and another two for me to row?" (Recorded from a 35-year-old male in Tallinn, 2012) 
Another popular joke tells about Lukashenko being invited to Venezuela (alternatively, the United Sates or Russia) to help the leaders with organizing an election - and winning their election himself (recorded from a 27-year-old female in Vitebsk, 2013). Finally, the Belarusian jokes also employ the recurrent frame of three characters coming to see God:

Once God invited three presidents to the heaven: those of the United States, Russia, and Belarus; and he says to them: "Dear presidents, I have invited you to announce unpleasant news: the doomsday is coming in two weeks. I want you to inform my three favorite peoples about it in a dignified way".

The statement of Bill Clinton on the radio and TV: "Brothers and sisters, I have two pieces of news for you: a good one and a bad one. The good one is that God exists. The bad one is that the doomsday is coming in two weeks".

The statement of Boris Yeltsin on the radio and TV: "Ladies and gentlemen, I have two pieces of news for you. Both are bad. The first one is that God exists. The second one is that the doomsday is coming in two weeks".

The statement of Lukashenko on the radio and TV: "People of free Belarus, I have two pieces of news for you. The first one: God acknowledged that I am the president. The second one: I am going to rule till the doomsday”. (Recorded from a 25-year-old female in Tartu, 2013)

Although in this article I strive to show the interconnection and indiscernibility of election folklore genres and themes from each other, it is also obvious that general rumors and humor about pro-Lukashenko election fraud also have distinct and recurrent motifs.

\section{GLADIATORS FOR LUKASHENKO}

In his research on Central Asian post-Soviet elections, Donnacha Ó Beacháin links their peculiarities to other non-democratic regimes, saying: "Thus, rather than one candidate emerging as a serious challenger, the vote is relatively evenly divided between the contenders so that the margin between incumbent and loser is overwhelming" (Ó Beacháin 2011: 218). He compares the role of the contenders to that of the warm-up gladiatorial acts of old, providing an opponent for the star of the stage and dying gracefully before the public view (ibid.: 223). This product of the communist past combined with the communisttrained present (ibid.: 224) is also undoubtedly the case of Belarus, where, according to the results of the presidential election, the alternative candidates 
receive an extreme minimum of voices. Little wonder that there is plenty of vernacular joking on that:

Ulakhovich [an alternative candidate in the 2015 election] and his wife voted at one of the election stations. The first vote for Ulakhovich! (Twitter 2015)

Kolen'ka's posts (Vk.com 2015):

The wife of Ulakhovich refused to vote for her husband, now he has twice fewer votes. (October 11, 2015)

I offered daddy to vote for Karatkevich. We laughed for about 5 minutes. (October 11, 2015)

At every election, however, there is a leading candidate among the alternative ones, receiving somewhat more votes than the others. He or she becomes the protagonist of election folklore along with Lukashenko, as it happened to Tatiana Karatkevich in the previous joke. Tatiana Karatkevich, the first female presidential candidate in Belarus, gained the official result of $4.44 \%$ votes a majority after Lukashenko. Her relative popularity, soft oppositionness, and active campaign attracted plenty of attention, and also condemnation. According to many rumors, Karatkevich was a project of the KGB, a candidate created to fake democracy and honest election in Belarus. These rumors were spread by her political opponents, also oppositionists, reluctant to unite around her as an alternative candidate and condemning her activity. As I noted, plenty of negativity originated from the oppositionists in exile - political refugees who themselves were unable to participate in Belarusian politics. The logic is well explained by one Facebook status: "The General Consulate of Belarus in ... did not include me in their election commission. So will they falsify the election results?" Forbidden to participate in the Belarusian political system, they often denounce those who are allowed to do it, by definition reproducing the illegal system. "KGB hire" (statystka ad KDB), "political fake" (palitychny feik), "clown" - these are only a few negative labels people attach to her on her public Facebook page (Facebook 2015). In spite of this critique from active oppositionist, Karatkevich apparently won the sympathies of many people. In accordance with other posts on her page, one of the followers wrote:

Tatiana, I voted for you, and many of my friends did (in Pinsk). 1,5 people [poltora cheloveka, a colloquial expression meaning 'very few'] of the older generation voted for Lukashenko. The reports of observers also show this. (Facebook 2015) 
Opinions about Karatkevich ranged from negative to positive, and sometimes the fact that she was female was stressed, whether seriously or jokingly undermining her ability of being a president. Political scientist Pavel Usov, for instance, claimed that Karatkevich was not ready for serious struggle due to her vulnerability - being a mother, whose child may become "a hostage in the hands of authorities" (Naviny.by 2015b). Another symptomatic attitude was expressed in Twitter posts: "Karatkevich should not be elected just because one day she will refuse to govern the country as she has nothing to wear" (Twitter 2015). These beliefs and humor point not only to the attitude towards the alternative candidates, but also to the attitude towards women and their active participation in the political life of Belarus.

\section{LOCAL ENDEAVORS AND FORCED VOTING}

In this part, I will concentrate on what is called "polling place shenanigans" the fraud of dishonest workers employed at the election to alter an honest vote (Sarvis 1998: 55). The methods of altering may be different - from changing the protocols to spoiling ballots with the 'wrong' answer, stealing votes, manipulating absentee ballots, and the so-called nursing home vote equal to absentee voting. Political operators can manipulate on a wider level, or this may be reduced to a more localized endeavor, where individuals might contend for single polling stations and precincts (ibid.: 66). Such local endeavors are the main focus of this section.

According to the interviews, local endeavors are believed to be pushed from above, and local superiors are given different instructions to follow at the election. These are primarily state organizations that may be manipulated in such a way, and one of the most common plots is related to forced voting at universities, when the students are strongly recommended to take part in preliminary vote - being intimidated or promised an extra day off.

The intimidations of students who don't go to the preliminary voting started.

In BSEU [Belarusian State Economic University], the students who vote tomorrow will get a day off on Saturday.

There are rumors in Polytechnic University that classes will be cancelled starting from Friday, so that everyone could get home on Thursday to vote. (Livejournal 2015) 
The interviews I recorded point to even more intimidation:

When ... was the class captain [at university], the dean and a tutor tried to force her to make the students vote for Lukashenko, enter the voting booths and check how they vote. She refused, and they said they would expel her and her group; they started real terror. She was scared, but Poles were visiting her at the same time and they promised to take her and the student group to Poland if they get expelled, so they should not be scared. (Recorded from a 28-year-old female in Vitebsk, 2014)

I worked for the OSCE [Organization for Security and Co-operation in Europe] during the last election, that is how I know. There were humorous cases, when an observer from the OSCE comes and a university lecturer is telling someone in the corridor how today or yesterday she made her students vote at the preliminary election. How she threatened them and so on. Why all this is needed - it is clear - to change the ballots at night. That is why he [Lukashenko] has a boost of about $25 \%$ from this preliminary vote fraud.

(Recorded from a 27-year-old male in Minsk, 2012)

Human rights activists published lists of recommendations meant for the students who were intimidated to vote at the preliminary stage of the election and/ or for Lukashenko. They recommended coming to the polling station in person only on the Election Day, an hour before it closed, and recording the threats from university officials (Livejournal 2015).

The threats by the university officials are similar to the activities of those providing luxurious food and performances at the elections. On the one hand, they themselves are also forced to do so, on the other, they do not resist these illegal practices either. This is well described by one of the interviewees:

I think that in case of power domineering, there are always cases of election falsification, even in case there is no central directive to do that. There are always people at their places who want to curry favor [vysluzhitsya] or understand that this power is beneficial for them.

(Recorded from a 30-year-old male in Minsk, 2013)

The illegality of many election practices, such as forced - often on a local level preliminary voting, conspiracy theories, such as Karatkevich being a KGB project, and general disillusionment in the system brought oppositionists to call for a boycott of the election. According to many, the votes of those who did not come to the election station presumably cannot be falsified. But as soon as one votes, the vote goes to Lukashenko: 
All the authorities need is that people come and throw a piece of paper today; then it is a matter of skills. I am not going and hundreds of my acquaintances in Belarus will not. No reason.

(Facebook status of one of my friends, 2015)

Rumors become not just repertoires of discontent, but also rhetorical strategies (Rahimi 2013: 85-86). According to many social network posts, neither their authors nor their families will "participate in legitimizing the regime" and in "playing shell game with the power". Others recognize that even though there are cases of fraud, they are not determinative, as the majority votes for Lukashenko anyway.

Still, boycott of the election pushed through the Internet in Belarus gradually replaces open protests that become less and less frequent. Since the late 1980s Belarusian protests had their distinctive forms and dates. Among others, sanctioned and unsanctioned meetings have been held on the so-called Dziady, a day in the autumn, when ancestors are traditionally commemorated in Belarus. Rejected during the Soviet times, in independent Belarus this date acquired a new meaning - commemorating the victims of the Soviet power as a means of constructing Belarusian identity independent from, if not hostile to, Russian influence. Also, protests used to accompany every election too, although now it happens less and less often. First, recent post-election protests were too violently suppressed, with many beaten and arrested. Many of the previous years' election candidates were imprisoned, and the protests lost their leaders. Belarusian political attitudes were largely influenced by the Ukrainian example; it is often repeated now that revolution and resistance lead to war. Finally, many oppositionists and their followers are just tired of unsuccessful attempts with no possibility of change. As a result, the 2015 election, with one of the highest results for Lukashenko in his presidential history, brought together only several hundred protesters (Svaboda 2015). Both in Iran and in Belarus, the protests are transferred to the internet discussions and speculations, "where subaltern voices gain the opportunity to articulate and, through networking, interactively define a world upside-down, [questioning] authority and the claims to authenticity of a political order" (Rahimi 2013: 91). Unable to participate in political processes otherwise, the opponents of Lukashenko now rather post their opinions on the Internet and disseminate rumors through this. The call for action is now not about the general protest, but on the Internet, about boycotting the elections. 


\section{GENRE INTERPLAY}

The election fraud rumors "can have varying degrees of substance and sensation" (Sarvis 1998: 43), becoming a mixture of direct testimony and legendary accounts (ibid.: 45). Another mixture I have already mentioned is that of different generic expressions. It is not only that election rumors, based on traditional themes and modern motifs, can also easily fall into the categories of contemporary legends, conspiracy theories, or even gossip. As shown above, sometimes it is even hard to distinguish between a joke and a rumor, and there are even more cases when jokes are not understandable without the knowledge of rumor, or they employ similar themes.

Humor and rumor intertwine so often that scholars even have to search for the boundaries between seriously presented truth claims and practical jokes directed at an audience (Ciardy 1965: 18; Fine \& Ellis 2010: 125-127; Bennett 1988, 1993). The same narratives may be equally used for both purposes: to raise a laugh and to recommend others to be alert. Similar to rumors, jokes provide a vent for frustration and an outlet for emotions (Banc \& Dundes 1986: 10; Dundes 1971: 51), if not become a "tiny revolution" (Orwell 1945: 1) and the weapon of the weak (Scott 1985). As Linda Dégh proves, the jokes and legends do not only get well together: they also provide necessary living conditions for each other (Dégh 1995: 293).

In the Belarusian case, jokes serve as a means for seriously probing and potentially debating a group's fears voiced in the rumors.

This case of ambiguity is obviously not unique, as "all genres leak" (Briggs \& Bauman 1992: 149), and there is no need not to make strict distinctions between different texts. Yet, it is important to look at the practices used in creating intertextual relations with other bodies of discourse (ibid.: 147, 163). Intertextuality is a dialogue among several writings, a relationship between a particular text and a prior discourse (ibid.: 147). Reproducing the power system, and talking and laughing about it, are all intertextually connected in Belarusian political discourse, providing powerful means for national and political identity constructions. Whether characterized as jokes or rumors, Belarusian election folklore becomes a flexible product of an ongoing struggle for making sense of the situation. Both rumors and jokes become instrumental in shaping and negotiating the attitude to the situation. As Timothy Tangherlini argues, and this can be applicable to jokes too, it is the indeterminate and fluid nature of [group] ideology that requires group members to tell stories to each other to confirm, define, and shape it. As such, the telling of a rumor should be considered a deeply political act. These stories are also deployed to sway others' actions, according to the narrator's own goal (Tangherlini 2007: 7-8). 
Tangherlini's arguments are well illustrated by the modality that Belarusian oppositionists have for spreading the rumors and the cases of misunderstanding the system due to the lack of comprehensive explanation of how the election system works. In turn, based on Missouri postwar election accounts, Sarvis suggests that when we do not know what is normal and what is not, it gives rise to the atmosphere of suspicion, and, as a result, to a rich oral tradition (Sarvis 1998: 46). Applicable to the Belarusian situation, the lack of knowledge about what is legal or normal and what is not, what is fraud or potential fraud or what is not, the absence of official information, rules, and accountability produces plenty of questions and consequent vernacular theorizing, as my own experience of voting in the Belarusian embassy did. The complexity of the system and the lack of answers also engender skepticism and irony. The multiplicity of intertextual links and generic precedents results in mixed, blurred, ambiguous, and contradictory generic framings (Briggs \& Bauman 1992: 163). The fieldwork data from Belarus enables us to theorize about genres and their interrelationships in practice.

\section{CONCLUSION}

The potential of multiple voting, wherein a single voter could travel from precinct to precinct, casting as many ballots as possible on Election Day (Sarvis 1998: 42), was possible in some American states until recently and became one of the rich sources of the election fraud folklore. Multiple voting seems to be still possible in the twenty-first century Belarus, and many more narratives tell about other possibilities of sham and fraudulent election in the country. A mixture of direct testimony, legendry accounts, and irony over the whole situation emerges in the interplay of jokes, news, and rumors. As fieldwork records show, the borders between these genres do not only fluctuate; they become almost irrelevant. Instead, intertextual connections of these texts persist, also reproducing the power system. Whether rumors about Potemkinism or jokes, the Belarusian election folklore becomes an expression of paternalist culture and a ritualistic demonstration of loyalty, even when it is mocked at. A very similar situation has been described for the Soviet Minsk 1950s election (Bohn 2011: 317), and, after half a century, many of its elements have been preserved to a large extent. The rumors and jokes related to elections usually combine various other significant tensions existing in the society. They circulate in the country all the time, not necessarily around the time of election (many were recorded in the interviews in the period between elections). On the one hand, 
they reproduce distinct themes, on the other, election fraud practices, according to the accounts, often overlap with one another. The gap between reality and the official rhetoric with its democratic façade is too stark, and the experiencebased folk expressions around the election become intertextual bridges that bring two sides together, whether to make sense of the disparity or to laugh at it.

\section{ACKNOWLEDGEMENTS}

This research was supported by Institutional Research Project "Tradition, Creativity, and Society: Minorities and Alternative Discourses" (IUT 2-43).

\section{RECORDINGS}

Recordings of interviews conducted in 2011-2015 in possession of the author.

\section{REFERENCES}

Alekseevsky 2010 = Alekseevskii, Mikhail. Anekdoty ot Ziuganova: Fol'klor v sovremennoi politicheskoi bor'be. [Jokes from Zuganov: Folklore in Contemporary Political Struggle.] Antropologicheskii forum onlain, No. 12. Available at http:// anthropologie.kunstkamera.ru/files/pdf/012online/12_online_alekseevsky.pdf, last accessed on May 29, 2017.

Andrews, Molly 2012. What is Narrative? Connecting Micro and Macro Political Stories. Novella. Available at http://www.novella.ac.uk/documents/Connecting_Micro_ and_Macro_Political_Stories.pdf, last accessed on May 22, 2017.

Arkhipova, Aleksandra 2012. Anekdoty o Putine i vyborakh 10 let spustia, ili est' li fol'lor "Snezhnoi revoliutsii"? [Jokes about Putin 10 Years Later, or Does the Folklore of "Snow Revolution" Exist?] Antropologicheskii forum onlain, No. 16, pp. 208-252. Available at http://anthropologie.kunstkamera.ru/files/pdf/016online/arkhipova2. pdf, last accessed on May 29, 2017.

Arkhipova \& Alekseevsky 2014 = Arkhipova, Aleksandra \& Alekseevskii, Mikhail (eds.) My ne nemy. [We Are Not Dumb.] Tartu: Nauchnoe izdatel'stvo ELM.

Astapova, Anastasiya 2015. When the President Comes: Potemkin Order as an Alternative to Democracy in Belarus. Negotiating Belarusianness: Political Folklore Betwixt and Between. Dissertationes Folkloristicae Universitatis Tartuensis 22. Tartu: University of Tartu Press, pp. 1-23. 
Attardo, Salvatore \& Raskin, Victor 1991. Script Theory Revis(it)ed: Joke Similarity and Joke Representation Model. Humor: International Journal of Humor Research, Vol. 4, Nos. 3-4, pp. 293-347. http://dx.doi.org/10.1515/humr.1991.4.3-4.293.

Banc, C. \& Dundes, Alan 1986. First Prize: Fifteen Years! An Annotated Collection of Romanian Political Jokes. Rutherford, N.J.: Fairleigh Dickinson University Press.

Bekus, Nelly 2010. Struggle over Identity: The Official and the Alternative "Belarusianness". Budapest: Central European University Press.

Bennett, Gillian 1988. Legend: Performance and Truth. In: Gillian Bennett \& Paul Smith (eds.) Monsters with Iron Teeth: Perspectives on Contemporary Legend III. Sheffield, UK: Sheffield Academic Press, pp. 13-36. Available athttp://collections.mun.ca/PDFs/ clegend/MonsterswithIronTeethPerspectivesonContemporaryLegendVol.03.pdf, last accessed on May 29, 2017.

Bennett, Gillian 1993. The Color of Saying: Modern Legend and Folktale. Southern Folklore, No. 50, pp. 19-32.

Blacker, Coit \& Rice, Condoleezza 2001. Belarus and the Flight from Sovereignty. In: Stephen D. Krasner (ed.) Problematic Sovereignty: Contested Rules and Political Possibilities. New York: Columbia University Press, pp. 224-250.

Bohn, Thomas M. 2011. "The People's Voice": The Elections to the Supreme Soviet of the USSR in 1958 in the Belarusian Capital Minsk. In: Ralph Jessen \& Hedwig Richter (eds.) Voting for Hitler and Stalin: Elections Under 20th Century Dictatorships. Frankfurt \& New York: Campus Verlag, pp. 309-336.

Briggs, Charles L. \& Bauman, Richard 1992. Genre, Intertextuality, and Social Power. Journal of Linguistic Anthropology, Vol. 2, No. 2, pp. 131-172. DOI: 10.1525/ jlin.1992.2.2.131.

Bugrova, Irina 1998. Politische Kultur in Belarus: Eine Rekonstruktion der Entwicklung vom Groß-fürstentum Litauen zum Lukaschenko-Regime. Mannheim: FKKS. Available at http://fkks.uni-mannheim.de/publikationen/fkks18.pdf, last accessed on May 29, 2017.

Ciardy, John 1965. Manner of Speaking. Saturday Review, November 27, p. 18.

Davis, John (ed.) 2013. The Arab Spring and Arab Thaw: Unfinished Revolutions and the Quest for Democracy. Farnham: Ashgate.

Dégh, Linda 1994. American Folklore and the Mass Media. Bloomington \& Indianapolis: Indiana University Press.

Dégh, Linda 1995. Symbiosis of Joke and Legend: A Case of Conversational Folklore. In: Linda Kinsey Adams (ed.) Narratives in Society: A Performer-Centered Study of Narration. FF Communications No. 255. Helsinki: Academia Scientiarum Fennica, pp. 285-305.

Dinkin, Robert J. (ed.) 2002. Election Day: A Documentary History. Westport, CT: Greenwood Press.

Dundes, Alan 1971. Laughter behind the Iron Curtain: A Sample of Rumanian Political Jokes. Ukrainian Quarterly, No. 27, pp. 50-59.

Erpyleva, Svetlana \& Magun, Artemi (eds.) 2014. Politika apolitichnykh: grazhdanskie dvizheniia $v$ Rossii 2011-2013. [The Politics of the Apolitical: The Civil Movements in Russia 2011-2013.] Moscow: Novoe literaturnoe obozrenie. 
Fabre, Genevieve 1993. Election Day Celebrations. In: Wolfgang Binder (ed.) Slavery in the Americas. Würzburg: Königshausen \& Neumann, pp. 403-420.

Fine, Gary Alan \& Ellis, Bill 2010. The Global Grapevine: Why Rumors of Terrorism, Immigration, and Trade Matter. Oxford: Oxford University Press.

Gamber, Wendy, \& Grossberg, Michael \& Hartog, Hendrik (eds.) 2003. American Public Life and the Historical Imagination. Notre Dame: University of Notre Dame Press.

Gencarella, Stephen Olbrys 2010. Gramsci, Good Sense, and Critical Folklore Studies: A Critical Reintroduction. Journal of Folklore Research, Vol. 47, No. 3, pp. 259264. http://dx.doi.org/10.2979/jfolkrese.2010.47.3.259.

Goldstuck, Arthur 1994. Ink in the Porridge: Urban Legends of the South African Elections. London: Penguin.

Granberg, Donald \& Burlison, James 1983. The Abortion Issue in the 1980 Elections. Family Planning Perspectives, Vol. 15, No. 5, pp. 231-238. http://dx.doi. org/10.2307/2135282.

Hermet, Guy \& Rose, Richard \& Rouquié, Alain 1978. Elections without Choice. London: Palgrave McMillan.

Honari, Ali 2014. From Virtual to Tangible Social Movements in Iran. In: Paul Aarts \& Francesco Cavatorta (eds.) Civil Society in Syria and Iran: Activism in Authoritarian Contexts. Boulder, CO: Lynne Rienner, pp. 143-168.

Jessen, Ralph \& Richter, Hedwig 2011. Non-Competitive Elections in 20th Century Dictatorships: Some Questions and General Considerations. In: Ralph Jessen \& Hedwig Richter (eds.) Voting for Hitler and Stalin: Elections Under 20th Century Dictatorships. Frankfurt \& New York: Campus Verlag, pp. 9-38.

Kamalipour, Yahya R. 2010. Media, Power, and Politics in the Digital Age: The 2009 Presidential Election Uprising in Iran. Lanham: Rowman \& Littlefield.

Kaschula, Russell H. 2004. Southern Africa: Contemporary Forms of Folklore. In: Philip M. Peek \& Kwesi Yankah (eds.) African Folklore: An Encyclopedia. New York \& London: Routledge, pp. 866-870.

Koestler, Arthur 1964. The Act of Creation. London: Hutchinson.

Korosteleva, Elena \& Lawson, Colin \& Marsh, Rosalind 2003. Afterword: The Presidential Election of September 2001. In: E. Korosteleva \& C. Lawson \& R. Marsh. Contemporary Belarus: Between Democracy and Dictatorship. London \& New York: Routledge, pp. 193-196.

Kozlov, Vladimir \& Mironenko, Sergei (eds.) 2005. Kramola: Inakomyslie v SSSR pri Khrushcheve i Brezhneve 1953-1982 gg. Rassekrechennye dokumenty Verkhovnogo suda i Prokuratury SSSR. [Revolt: Dissidence in Russia in the Era of Khruschev and Brezhnev 1953-1982. Declassified Documents of the USSR Public Prosecutor's Office.] Moscow: Materik.

Latvala, Pauliina 2014. On Election Day the Husband Tied His Wife to a Table Leg to Stop Her from Voting: Political Narratives, Gender and Archived Heritage in Finland. Folklore: Electronic Journal of Folklore, No. 57, pp. 117-140. http:// dx.doi.org/10.7592/FEJF2014.57.latvala.

Merl, Stephan 2011. Elections in the Soviet Union, 1937-1989: A View into a Paternalistic World from Below. In: Ralph Jessen \& Hedwig Richter (eds.) Voting for Hitler and Stalin: Elections Under 20th Century Dictatorships. Frankfurt \& New York: Campus Verlag, pp. 276-308. 
Muravchik, Joshua 2013. Trailblazers of the Arab Spring: Voices of Democracy in the Middle East. New York \& London: Encounter Books.

Ó Beacháin, Donnacha 2011. Faking It: Neo-Soviet Electoral Politics in Central Asia. In: Ralph Jessen \& Hedwig Richter (eds.) Voting for Hitler and Stalin: Elections Under 20th Century Dictatorships. Frankfurt \& London: Campus Verlag, pp. 204-230.

Oring, Elliott 2004. Risky Business: Political Jokes under Repressive Regimes. Western Folklore, Vol. 63, No. 3, pp. 209-236. Available at https://www.jstor.org/ stable/25474676?seq=1\#page_scan_tab_contents, last accessed on May 29, 2017.

Orwell, George 1945. Funny, But Not Vulgar. Leader, July 28.

Patterson, Thomas E. 2003. The Vanishing Voter: Public Involvement in an Age of Uncertainty. New York: Vintage Books.

Patzelt, Werner J. 2011. Elections in Modern Dictatorships: Some Analytical Considerations. In: Ralph Jessen \& Hedwig Richter (eds.) Voting for Hitler and Stalin: Elections Under 20th Century Dictatorships. Frankfurt \& London: Campus Verlag, pp. 126-145.

Pound, Louise 1959. Nebraska Folklore. Lincoln: University of Nebraska Press.

Rahimi, Babak 2013. The Politics of Informal Communication: Conspiracy Theories and Rumors in the 2009 (Post-)Electoral Iranian Public Sphere. In: Greg Dalziel (ed.) Rumor and Communication in Asia in the Internet Age. London \& New York: Routledge, pp. 78-93.

Richter, Hedwig 2011. Mass Obedience: Practices and Functions of Elections in the German Democratic Republic. In: Ralph Jessen \& Hedwig Richter (eds.) Voting for Hitler and Stalin: Elections Under 20th Century Dictatorships. Frankfurt \& London: Campus Verlag, pp. 103-125.

Rudling, Per Anders 2015. The Rise and Fall of Belarusian Nationalism, 1906-1931. Pittsburgh, PA: University of Pittsburgh Press.

Santino, Jack 1994. All Around the Year: Holidays and Celebrations in American Life. Urbana \& Chicago: University of Illinois Press.

Sarvis, William R. 1998. The Folklore and Oral History of Election Fraud in Rural Postwar Missouri. Mid-America Folklore, Vol. 26, Nos. 1-2, pp. 42-70.

Savchenko, Andrew 2009. Belarus - A Perpetual Borderland. Leiden: Brill Academic Publishers.

Schudson, Michael 1998. The Good Citizen: A History of American Civic Life. New York: The Free Press.

Scott, James C. 1985. Weapons of the Weak: Everyday Forms of Peasant Resistance. New Haven: Yale University Press.

Scott, James C. 1990. Domination and the Arts of Resistance: Hidden Transcripts. New Haven and London: Yale University Press. Available at https:/libcom.org/files/ scott_dominationandresistance.pdf, last accessed on May 30, 2017.

Tangherlini, Timothy R. 2007. Rhetoric, Truth, and Performance: Politics and the Interpretation of Legends. Indian Folklife: A Quarterly Newsletter from National Folklore Support Centre, Vol. 25, pp. 8-12. Available at http://tango.bol.ucla.edu/ publications/A73.pdf, last accessed on May 29, 2017. 
Tsipursky, Gleb 2011. Integration, Celebration, and Challenge: Soviet Youth and Elections, 1953-1968. In: Ralph Jessen \& Hedwig Richter (eds.) Voting for Hitler and Stalin: Elections Under 20th Century Dictatorships. Frankfurt \& London: Campus Verlag, pp. 81-102.

Varga, Katalin 2015. Creativity and Humor in the Online Folklore of the 2014 Political Elections in Hungary. Folklore Fellows Summer School 2015. Oral presentation.

Watts, Linda S. 2006. Election Day. In: Linda S. Watts. Encyclopedia of American Folklore. New York: Facts On File, pp. 125-126.

Weddady, Nasser \& Ahmari, Sohrab (eds.) 2012. Arab Spring Dreams: The Next Generation Speaks Out for Freedom and Justice from North Africa to Iran. New York: Palgrave MacMillan.

White, Joyce M. 1993. Meaning and Cultural Expression: New England Election Day Cake. Digest: A Review for the Interdisciplinary Study of Food, Vol. 13, Nos. 1-2, pp. 9-15.

Yurchak, Alexei 1997. The Cynical Reason of Late Socialism: Power, Pretense, and the Anekdot. Public Culture, Vol. 9, No. 2, pp. 161-188. DOI: 10.1215/08992363-9$2-161$.

Zaslavsky, Victor \& Brym, Robert J. 1978. The Functions of Elections in the USSR. Soviet Studies, Vol. 30, No. 3, pp. 362-371. http://dx.doi.org/10.1080/09668137808411193.

\section{INTERNET SOURCES}

BBC News 2001 = Belarus Vote 'Neither Free nor Fair'. BBC News, September 10. Available at http://news.bbc.co.uk/2/hi/europe/1534621.stm, last accessed on May 30, 2017.

BBC News 2006 = Belorussiia: 1994-2006 [Belarus: 1994-2006.] BBC Russian.com, March 16. Available at http://news.bbc.co.uk/hi/russian/in_depth/2006/belarus/ newsid_4810000/4810062.stm, last accessed on May 30, 2017.

Facebook 2015 = Tatiana Karatkevich. Available at https://www.facebook.com/tania. karatkevich, last accessed on May 26, 2017.

Google play 2015 = Lida: Save the Elections. Available at: https://play.google.com/store/ apps/details?id=ru.lanaer.lida, last accessed on May 29, 2017.

Grodno 2015 = Bufet na prezidentskom uchastke raduet izbiratelei smeshnymi tsenami. [The Buffet at the President's Election Station Makes the Voters Happy with Its Preposterous Prices.] Grodno24, October 11. Available at http://grodno24. com/belarus/bufet-na-prezidentskom-uchastke-raduet-izbiratelej-smeshnyimiczenami.html, last accessed on May 30, 2017.

Livejournal 2012 = Tselibat, piraty i greshnye zaitsy. [Celibacy, Pirates and Sinful Hares.] Livejournal, December 1. Available at http://diak-kuraev.livejournal. com/267282.html?nojs=1\&page=2, last accessed on May 30, 2017. 
Livejournal 2015 = Nachalis' zapugivaniia studentov za neiavku na dosrochnoe golosovanie. [The Intimidations of Students Regarding No-Show for the Preliminary Voting Started.] Livejournal, October 5. Available at http://toxaby. livejournal.com/645170.html, last accessed on May 30, 2017.

Minsknews 2015 = Na izbiratel'nykh uchastkakh 11 oktiabria minchan ozhidaet massa priiatnykh siurprizoviu. [At the Election Stations on October 11 the Residents of Minsk Will Be Faced with Many Pleasant Surprises.] Minsknews, October 9. Available at http://minsknews.by/blog/2015/10/09/na-izbiratelnyih-uchastkah11-oktyabrya-minchan-ozhidaet-massa-priyatnyih-syurprizov/, last accessed on May 30, 2017.

Naviny.by $2015 \mathrm{a}=$ Vybory prezidenta Belarusi-2015: Onlain-reportazh. [The Election of the Belarusian President 2015: Online-Report.] Naviny.by, October 11. Available at http://naviny.by/rubrics/elections/2015/10/11/ic_articles_623_189997/, last accessed on May 30, 2017.

Naviny.by 2015 b = Pavel Usov. TEORIIA: Pochemu Tat'iana Korotkevich - feikovyi kandidat. [Pavel Usov. A Theory: Why Tatiana Karatkevich is a Fake Candidate.] Naviny.by, May 24. Available at: http://naviny.by/rubrics/opinion/2015/05/24/ ic_articles_410_188958/, last accessed on May 30, 2017.

Pikabu 2015 = Golosovanie prokhodit v tiazhelykh usloviiakh. [The Voting is Being Held in Hard Conditions.] Pikabu. Available at http://pikabu.ru/story/golosovanie_ prokhodit_v_tyazhelyikh_usloviyakh_3703814, last accessed on May 30, 2017.

Ru.tsn.ua $2010=\mathrm{V}$ tsentre Minska protivniki Lukashenko poprosili 'Sashu' uiti. [In the Center of Minsk the Opponents of Lukashenko asked 'Sasha' to Leave.] Ru.tsn. ua, November 24. Available at http://ru.tsn.ua/svit/v-centre-minska-protivnikilukashenko-poprosili-sashu-uyti.html, last accessed on May 30, 2017.

Svaboda 2015 = Spantannaia Ploshcha-2015: ad Kastrychnitskai da ploshchy Nezalezhnas'tsi. [Spontaneous Square-2015: From Kastrychnitskaya to Nezalezhnasc' Square.] Svaboda, October 11. Available at http://www.svaboda. mobi/a/27300520.html, last accessed on May 30, 2017.

The Central Commission 2004 = Ukaz Prezidenta Respubliki Belarus' 7 sentiabria 2004 g. N 431 g. o naznachenii respublikanskogo referenduma. [The Decree of the President of the Republic of Belarus from September 7, 2004, No. 431, about Conducting the Republican Referendum.] Available at http://www.rec.gov.by/sites/ default/files/pdf/Archive-Referenda-2004-Ukaz.pdf, last accessed on May 30, 2017.

Twitter 2015 = \#выборытут [electionhere.] Available at https://twitter.com/hashtag/\%D 0\%B2\%D1\%8B\%D0\%B1\%D0\%BE\%D1\%80\%D1\%8B\%D1\%82\%D1\%83\%D1\%82, last accessed on May 26, 2017.

United Civil Party 2015 = Sensatsiia: foto i video 'karusel'shchikov'! [Sensation! Photos and Videos of Merry-Go-Rounders!] Ob"edinennaia grazhdanskaia partiia, October 9. Available at http://ucpb.org/news/society/sensatsiya-foto-i-video-karuselshchikov, last accessed on May 30, 2017.

Vk.com 2015 = Grustnyi Kolen'ka. [Sad Kolen'ka.] Available at https://vk.com/kolyasik_ prod, last accessed on May 24, 2017. 
Youtube 2006 = Lukashenko: my sfal'sifitsirovali poslednie prezidentskie vybory. [Lukashenko: We Falsified the Latest Presidential Election.] Youtube, November 23. Available at https://www.youtube.com/watch?v=g982KGUcrKk, last accessed on May 30, 2017.

Youtube 2015 = "Ia idu na vybory, potomu chto..." ["I Am Going to the Election Because..."] Youtube, October 2. Available at https://www.youtube.com/ watch?v=TrmPuGZk2hs, last accessed on May 30, 2017. 